\title{
A szegedi Fogászati és Szájsebészeti Klinikán diagnosztizált, az orofacialis régiót érintő jóindulatú daganatok és daganatszerü laesiók klinikopatológiai retrospektív epidemiológiai analízise (1960-2014)
}

\author{
Sonkodi István dr. ${ }^{1}$ - Boda Krisztina ${ }^{2}$ - Decsi Gábor dr. ${ }^{1}$ \\ Buzás Kristóf dr. ${ }^{1}$ - Nagy Katalin dr. ${ }^{3}$ \\ Szegedi Tudományegyetem, ${ }^{1}$ Fogorvostudományi Kar, Orális Medicina Részleg, \\ 2Általános Orvostudományi Kar, Orvosi Informatikai Intézet, \\ ${ }^{3}$ Fogorvostudományi Kar, Szájsebészeti Tanszék, Szeged
}

Bevezetés: Az 54 éves (1960-2014) retrospektív klinikopatológiai analízis a szegedi Fogászati és Szájsebészeti Klinika Orális Medicina Részlegén diagnosztizált jóindulatú orofacialis daganatok és daganatszerű elváltozások utánkövetéses epidemiológiai eredményeinek bemutatására irányult.

Anyag és módszer: Összesen 14661 biopszia történt, amelyek közül 7491 (51,09\%) jóindulatú daganatos beteget vontunk be számítógépes vizsgálatunkba.

Eredmények: A betegek átlagéletkora 55,3 év, a férfiak száma $2823(37,7 \%)$, a nőké 4668 (62,3\%) volt. A férfi : nő arány 1 : 1,65 volt. Az 51-60 éves korcsoportból emelhető ki a legtöbb, 1280 eset (17,1\%), és ezen belül 1014 eset (13,6\%) alakult ki gyermekkorban és 6477 eset (86,3\%) felnőttkorban. Dominálóan több volt a nem neoplasma $(6420,85,7 \%)$, mint a neoplasma $(1071,14,3 \%)$, ezenfelül pedig több volt a mesenchymalis $(5574,74,4 \%)$, mint a nem mesenchymalis $(982,13,1 \%)$ daganat. A leggyakoribb daganattípus az irritációs fibroma volt $(1806,32,4 \%)$. A gyulladásos/fertőzéses csoportban a legtöbbször granuloma pyogenicumot $(465,8,3 \%)$ észleltünk. A cysták közül a mucokele $(805,10,7 \%)$, a fejlődési rendellenességek közül pedig a haemangioma $(815,14,6 \%)$ fordult elő a leggyakrabban. A daganatok lokalizációját tekintve a legtöbb esetet az ajkon $(2081,27,8 \%)$, a gingiván $(2024,27,0 \%)$, a buccán $(1069,14,3 \%)$, a nyelven $(981,13,1 \%)$ és az arcbőrön $(695,9,3 \%)$ regisztráltuk. Az orofacialis jóindulatú lágyrész-daganatok döntő többségét a biopsziavételt követően cryo- vagy lézer-, esetenként kombinált (cryo + lézer) kezelésben részesítettük.

Következtetés: A jelen vizsgálatban a leggyakoribb jóindulatú tumor az irritációs fibroma volt, és a legtöbb elváltozás az alsó ajkakon fordult elő. A tanulmányok összehasonlító vizsgálatát megnehezítették a diagnosztikai klasszifikációban és a metodológiában alkalmazott különbözőségek, valamint a változó földrajzi és populációs eltérések. Orv Hetil. 2018; 159(37): 1516-1524.

Kulcsszavak: orofacialis epidemiológia, orofacialis jóindulatú daganatok és daganatszerû laesiók, retrospektív analízis

A clinicopathological retrospective epidemiological analysis of benign tumors and tumor-like lesions in the oral and maxillofacial region, diagnosed at the University of Szeged, Department of Oral Medicine (1960-2014)

Introduction: In a clinicopathological retrospective epidemiological study we investigated benign tumors and tumorlike lesions located in the orofacial region, diagnosed at the Universiy of Szeged, Department of Oral Medicine. Method: During a 54-year period (1960-2014), 14661 biopsies were taken. The included subjects were 7491 patients diagnosed with benign tumors and tumor-like lesions. 
Results: The average age of patients was 55.3 years, $2823(37.7 \%)$ patients were male and $4668(62.3 \%)$ female. The male : female ratio was $1: 1.65$. Most of the patients included in the study were aged 51-60 (1280, 17.1\%). The number of children was $1014(13.6 \%)$ and the number of adults was 6477 (86.3\%). The number of non-neoplasms was $6420(85.7 \%)$, being significantly higher than the number of neoplasms (1071, 14.3\%). Most of the lesions were of mesenchymal origin $(5574,77.4 \%)$; the number of lesions of non-mesenchymal origin was $982(13.1 \%)$. The most prevalent type of lesions was traumatic fibroma (fibrosis): $1806(32.4 \%)$. The most common lesion type in the group of lesions of infectious/inflammational origin was pyogenic granuloma, the number of which was $465(8.3 \%)$. The most common cystic lesion was mucocele $(805,10.7 \%)$. Hemangioma was the most frequent lesion type among developmental anomalies with the number of 815 (14.6\%). The most common location of the lesions was the lip in 2081 cases $(27.8 \%)$, followed by the gingiva in 2024 cases $(27.0 \%)$, bucca in 1069 cases (14.3\%), tongue in 981 cases $(13.1 \%)$, and the facial skin in 695 cases $(9.3 \%)$. After taking biopsy, the majority of benign lesions were treated with cryo-, laser-, or combined (cryo and laser) surgery.

Conclusion: The present computer-aided study showed that irritational fibroma was the most common orofacial benign tumor, and the lip was the most frequent location. The diagnostic classification and the methodology are considerably different in the majority of the studies, which may hinder the exact comparison with other surveys from different regions of the world.

Keywords: orofacial epidemiology, orofacial benign tumor, tumor-like lesions, retrospective study

Sonkodi I, Boda K, Decsi G, Buzás K, Nagy K. [A clinicopathological retrospective epidemiological analysis of benign tumors and tumor-like lesions in the oral and maxillofacial region, diagnosed at the University of Szeged, Department of Oral Medicine (1960-2014)]. Orv Hetil. 2018; 159(37): 1516-1524.

(Beérkezett: 2018. április 16.; elfogadva: 2018. május 27.)

\section{Rövidítések}

$\mathrm{CT}=$ (computer tomography) komputertomográfia; $\mathrm{KSH}=$ Központi Statisztikai Hivatal; MRI = (magnetic resonance imaging) mágnesesrezonancia-vizsgálat; SZTE = Szegedi Tudományegyetem; $\mathrm{UH}=$ ultrahang; $\mathrm{WHO}=($ World Health Organization) Egészségügyi Világszervezet

$\mathrm{Az}$ orofacialis régió jóindulatú daganatainak és daganatszerü elváltozásainak incidenciája földrajzilag és ezen belül országonként is változik [1-17].

Klinikánk mint az 1973-ban kiadott sztomatoonkológiai módszertani levélben [18] kijelölt és megbízott intézmény három dél-magyarországi megye onkológiai decentrumaként már korábban, 1968 óta bekapcsolódott a szájüregi és maxillofacialis daganatos betegek szürésébe, kezelésébe, rehabilitációjába és gondozásába.

Az oralis és a maxillofacialis régió jóindulatú daganatos megbetegedéseinek prevalenciájával, incidenciájával és morbiditásával több hazai $[10,11,19,20]$ és külföldi szerző [1-6, 8, 9, 12-16, 21-39] foglalkozott. Ezáltal az ilyen irányú onkoepidemiológiai ismereteink bővültek, de még mindig kiegészíthetők hézagpótló, összehasonlításra alkalmas nagyobb és többirányú vizsgálatok eredményeivel. A jelen tanulmány a klinikánk Orális Medicina Részlegén diagnosztizált, többségében nem odontogen és osteogen, jóindulatú lágyrész-daganatos és daganatszerú állapotok beteganyagára szorítkozik.

A tudományos epidemiológiai vizsgálatok többsége a jóindulatú daganatok archív klinikai és biopszás anyagaiból származó hisztopatológiai $[2,3,6,29,35,36,40$, 41], döntően retrospektív [2, 6, 11, 14, 16, 20, 25, 35,
40], csak ritkán prospektív [12] analízisére épül. Kevés számban fordultak elő klinikai hátterű tanulmányok [21, 28], és csak néhány felmérés számolt be a jelen munkánkhoz hasonló több évtizedes klinikopatológiai [3, 11, 24, 40, 42] vizsgálatról.

Célunk az volt, hogy számítógépes analízissel meghatározzuk a dél-magyarországi régió jóindulatú daganatainak relatív gyakoriságát és multicentrikus megoszlását, ezáltal összehasonlításra alkalmas adatokat szolgáltatva további ilyen irányú vizsgálatokhoz.

\section{Anyag és módszer}

A SZTE Fogászati és Szájsebészeti Klinikájához mint központilag kijelölt sztomatoonkológiai decentrumhoz három megye (Bács-Kiskun, Békés és Csongrád megye) tartozik, az 1960-2014-es években átlagosan 1,7 millió fónyi népességgel $(\mathrm{KSH})$, ami az ország lakosságának megközelítőleg 15\%-a. Klinikánk átlagos évenkénti betegforgalma 6000-10 000 között változik.

Jelen munkánk a klinika Orális Medicina Részlegének járóbeteg-forgalmára korlátozódik, amely az alapellátásból és a klinikánkon spontán jelentkező sztomatoonkológiai betegekből származik. Az évenkénti betegforgalom 3000-4000, amiból az új betegek száma 900-1300. Évente átlagosan 250-350 jóindulatú betegséget regisztráltunk.

Így a jelen tudományos célú deszkriptív és analitikus epidemiológiai vizsgálatba összesen 7491 (51,0\%) benignus lágyrész-daganatos beteget vontunk be, és kizártuk azokat az eseteket (1991, 13,5\%), amelyek nem 
1. táblázat |A jóindulatú daganatok és daganatszerú állapotok nem és típus szerinti megoszlása

\begin{tabular}{|c|c|c|c|c|c|c|c|c|c|}
\hline & & & & Férfi & $\%$ & Nő & $\%$ & Összes & $\%$ \\
\hline \multirow{13}{*}{ 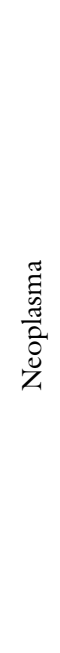 } & \multirow{7}{*}{\multicolumn{2}{|c|}{ 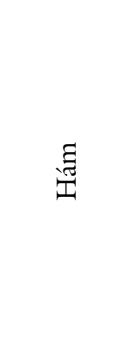 }} & Papilloma & 207 & $48,90 \%$ & 216 & $51,10 \%$ & 423 & $5,60 \%$ \\
\hline & & & Verruca vulgaris & 29 & $61,70 \%$ & 18 & $38,30 \%$ & 47 & $0,60 \%$ \\
\hline & & & Verruca seborrhoica & 159 & $75,00 \%$ & 53 & $25,00 \%$ & 212 & $2,80 \%$ \\
\hline & & & Naevus pigmentosus & 52 & $23,20 \%$ & 172 & $76,80 \%$ & 224 & $3,00 \%$ \\
\hline & & & Morbus Heck (fokális epithelialis hyperplasia) & 0 & $0,00 \%$ & 16 & $100,00 \%$ & 16 & $0,20 \%$ \\
\hline & & & Pleomorph adenoma & 24 & $40,00 \%$ & 36 & $60,00 \%$ & 60 & $0,80 \%$ \\
\hline & & & Összes hám & 471 & $48,00 \%$ & 511 & $52,00 \%$ & 982 & $13,10 \%$ \\
\hline & \multirow{6}{*}{\multicolumn{2}{|c|}{ 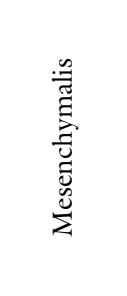 }} & Lipoma & 16 & $45,70 \%$ & 19 & $54,30 \%$ & 35 & $0,50 \%$ \\
\hline & & & Fibrolipoma & 3 & $50,00 \%$ & 3 & $50,00 \%$ & 6 & $0,10 \%$ \\
\hline & & & Neurilemmoma (schwannoma) & 6 & $46,20 \%$ & 7 & $53,80 \%$ & 13 & $0,20 \%$ \\
\hline & & & Neurofibroma & 2 & $33,30 \%$ & 4 & $66,70 \%$ & 6 & $0,10 \%$ \\
\hline & & & Leiomyoma & 1 & $33,30 \%$ & 2 & $66,70 \%$ & 3 & $0,00 \%$ \\
\hline & & & Granulomasejtes tumor (Abrikossoff) & 8 & $30,80 \%$ & 18 & $69,20 \%$ & 26 & $0,30 \%$ \\
\hline & & & Összes neoplasma & 507 & $47,30 \%$ & 564 & $52,70 \%$ & 1071 & $14,30 \%$ \\
\hline \multirow{27}{*}{ 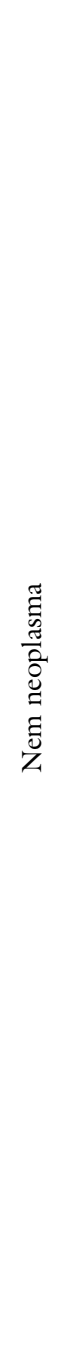 } & \multirow{21}{*}{ 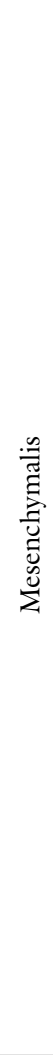 } & \multirow{8}{*}{ 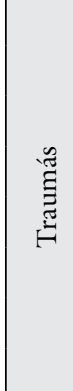 } & Papillaris hyperplasia & 42 & $46,20 \%$ & 49 & $53,80 \%$ & 91 & $1,60 \%$ \\
\hline & & & Fibroma (irritációs) & 418 & $23,10 \%$ & 1388 & $76,90 \%$ & 1806 & $32,40 \%$ \\
\hline & & & Fibroepithelioma (polyp) & 105 & $25,30 \%$ & 310 & $74,70 \%$ & 415 & $7,40 \%$ \\
\hline & & & Fibrogranuloma & 8 & $28,60 \%$ & 20 & $71,40 \%$ & 28 & $0,50 \%$ \\
\hline & & & Granuloma fissuratum & 196 & $53,00 \%$ & 174 & $47,00 \%$ & 370 & $6,60 \%$ \\
\hline & & & Epulis (parodontoma) & 232 & $29,60 \%$ & 552 & $70,40 \%$ & 784 & $14,10 \%$ \\
\hline & & & Fibrohaemangioma & 7 & $38,90 \%$ & 11 & $61,10 \%$ & 18 & $0,30 \%$ \\
\hline & & & Összes traumás & 1008 & $28,70 \%$ & 2504 & $71,30 \%$ & 3512 & $63,00 \%$ \\
\hline & & \multirow{9}{*}{ 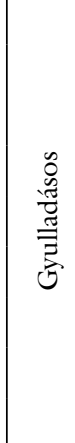 } & Granuloma pyogenicum & 158 & $34,00 \%$ & 307 & $66,00 \%$ & 465 & $8,30 \%$ \\
\hline & & & Granuloma gravidarum & 0 & $0,00 \%$ & 191 & $100,00 \%$ & 191 & $3,40 \%$ \\
\hline & & & Tonsilla linguae & 52 & $41,30 \%$ & 74 & $58,70 \%$ & 126 & $2,30 \%$ \\
\hline & & & Cheloid & 12 & $38,70 \%$ & 19 & $61,30 \%$ & 31 & $0,60 \%$ \\
\hline & & & Idegentest-granuloma & 5 & $26,30 \%$ & 14 & $73,70 \%$ & 19 & $0,30 \%$ \\
\hline & & & Postextractiós granuloma & 15 & $46,90 \%$ & 17 & $53,10 \%$ & 32 & $0,60 \%$ \\
\hline & & & Cheilitis granulomatosa & 8 & $36,40 \%$ & 14 & $63,60 \%$ & 22 & $0,40 \%$ \\
\hline & & & Hypertrophia papillae circumvallate & 7 & $35,00 \%$ & 13 & $65,00 \%$ & 20 & $0,40 \%$ \\
\hline & & & Összes gyulladásos & 257 & $28,40 \%$ & 649 & $71,60 \%$ & 906 & $16,30 \%$ \\
\hline & & \multirow{3}{*}{ FM } & Haemangioma & 377 & $46,30 \%$ & 438 & $53,70 \%$ & 815 & $14,60 \%$ \\
\hline & & & Lymphangioma & 12 & $37,50 \%$ & 20 & $62,50 \%$ & 32 & $0,60 \%$ \\
\hline & & & Összes fejlődési rendellenesség & 389 & $45,90 \%$ & 458 & $54,10 \%$ & 847 & $15,20 \%$ \\
\hline & & EM & Egyéb (ritka daganatok) & 96 & $43,60 \%$ & 124 & $56,40 \%$ & 220 & $3,90 \%$ \\
\hline & \multirow{6}{*}{\multicolumn{2}{|c|}{$\frac{\pi}{3}$}} & Cysta dermoides & 3 & $75,00 \%$ & 1 & $25,00 \%$ & 4 & $0,10 \%$ \\
\hline & & & Atheroma & 18 & $72,00 \%$ & 7 & $28,00 \%$ & 25 & $0,30 \%$ \\
\hline & & & Cysta epidermoides & 24 & $75,00 \%$ & 8 & $25,00 \%$ & 32 & $0,40 \%$ \\
\hline & & & Mucokele & 491 & $61,00 \%$ & 314 & $39,00 \%$ & 805 & $10,70 \%$ \\
\hline & & & Ranula & 30 & $43,50 \%$ & 39 & $56,50 \%$ & 69 & $0,90 \%$ \\
\hline & & & Összes cysta & 566 & $60,50 \%$ & 369 & $39,50 \%$ & 935 & $12,50 \%$ \\
\hline \multicolumn{4}{|c|}{ Összes nem neoplasma } & 2316 & $36,10 \%$ & 4104 & $63,90 \%$ & 6420 & $85,70 \%$ \\
\hline \multicolumn{4}{|c|}{ Összes mesenchymalis } & 1786 & $32,00 \%$ & 3788 & $68,00 \%$ & $\mathbf{5 5 7 4}$ & $74,40 \%$ \\
\hline \multicolumn{4}{|c|}{ Összes } & 2823 & $37,70 \%$ & 4668 & $62,70 \%$ & 7491 & $100,00 \%$ \\
\hline
\end{tabular}


minden szempontból feleltek meg a tudományos feldolgozás szempontjainak (például hiányos adatok, elmaradt betegjelentkezések, az egyértelmü klinikai diagnózis [mucokele, haemangioma] miatt elmaradt szövettani mintavételek).

Vizsgálatunkba korhatár kiszabása nélkül választottuk a betegeket, tehát nem specifikus populációs csoportokba (gyermek, felnőtt). Az Orális Medicina járóbeteg-ambulanciánkon kezelt és ellenőrzött, elsősorban jóindulatú lágyrész-daganatos betegek klinikopatológiai számítógépes adatbázisának analízisét tekintettük kiemelendőnek.

Minden sztomatoonkológiai beteg jelentkezésekor 1968 óta kitöltünk egy általunk összeállított és bevezetett, számítógépes epidemiológiai szempontból (kor, nem, lokalizáció, etiológia, szisztémás betegségek, kezelés, szövettan stb.) tudományos feldolgozásra és a napi gyakorlati nyilvántartásra alkalmas kódolt adatlapot. A klinikai adatlapok digitalizálását követően (Microsoft Office Excel) az adatokat kezdetben lyukkártyán őriztük, ma merevlemezen tároljuk, későbbi egyéb irányú vizsgálatokhoz elektronikus adatbankot képezve.

A fizikális extra- és intraoralis klinikai vizsgálatokat, kezeléseket 1968 és 2006 között egy személyben az oralis medicinában és patológiában képzett specialista végezte, a fennmaradó időben pedig még két klinikussal megosztva és konzultálva történtek a betegellátások. A klinikailag jóindulatú daganatokból vagy daganatszerü állapotokból az esetek többségében excizionális vagy körtrepános próbakimetszés történt a végső hisztopatológiai diagnózis felállításához (SZTE Patológiai Intézet).

A daganatok konzisztenciájától és mélységi elhelyezkedésétől függően szükség esetén röntgen-, UH-, CT-, MRI-vizsgálat történt, és bizonyos betegségekben aspirációs citológia is megelőzte a kezelést. Az elsősorban lágyrész-daganatos betegségek döntő többségében a kezelések a járóbeteg-ambulancián egyszeri beavatkozásként (biopszia + sebészet, lézer, cryo és kombináltan cryo + lézer) történtek. A feldolgozást az Etikai Bizottság jóváhagyásával végeztük.
A daganatok osztályozási rendszerének tekintetében elsősorban a WHO szájüregi és maxillofacialis onkológiai klasszifikációját, az Európai Unió ajánlásait [26, 4244] vettük alapul. Az elváltozásokat alapvetően nem odontogen neoplasticus és nem neoplasticus eredetük szerint csoportosítottuk, de figyelembe vettünk még több, egyéb irányú daganatfelosztást is (hámeredet, mesenchymalis eredet, reaktív és traumás, gyulladásos, pigmentált elváltozások, cysták, benignus nyálmirigy- és lágyrész-daganatok stb.) [37].

A statisztikai analízishez az SPSS statisztikai szoftver 24-es verzióját és a khi-négyzet-próbát alkalmaztuk.

\section{Eredmények}

A klinikánkhoz tartozó három megye népességében (1,7 millió) 1960 és 2014 között 9482 (közel 0,6\%) orofacialis jóindulatú daganatot és daganatszerú állapotot diagnosztizáltunk. Ez a klinikai betegforgalomhoz viszonyítva (338 250) 2,8\%-ot, az Orális Medicina Részleg betegforgalmára (35 086) számítva 27,02\%-ot jelent, amiből 14446 beteg $(41,2 \%)$ egyéb szájnyálkahártyabetegségben szenvedett. 54 év alatt a klinika Orális Medicina Részlegén összesen 14661 (100\%) biopszia történt, amelyek közül 7491 eset $(51,0 \%)$ tartozott az elemezhető, jóindulatú lágyrész-daganatok közé. A legfiatalabb beteg 3 hetes, a legidősebb beteg 94 éves, az átlagos életkor 53,3 $\pm 18,29$ év volt. Összesen 1014 eset (13,6\%) fordult elő a gyermekkorú (17 év alatti) és 6477 eset $(86,3 \%)$ a felnőttkorú betegek között.

Év, kor és nem szerinti megoszlás alapján a feldolgozásra alkalmas 7491 jóindulatú daganat vagy daganatszerü állapot közül a legtöbb eset az 51-60 éves korcsoportból (1280, 17,1\%) emelhető ki.

A nemek szerinti megoszlást tekintve a nók domináltak: $4668(62,3 \%)$, és csak kevesebb számban voltak a férfiak: $2823(37,7 \%)$ (1. táblázat). A férfi : nő arány $1: 1,65$ volt $(\mathrm{p}=0,0001)$ (1. ábra).

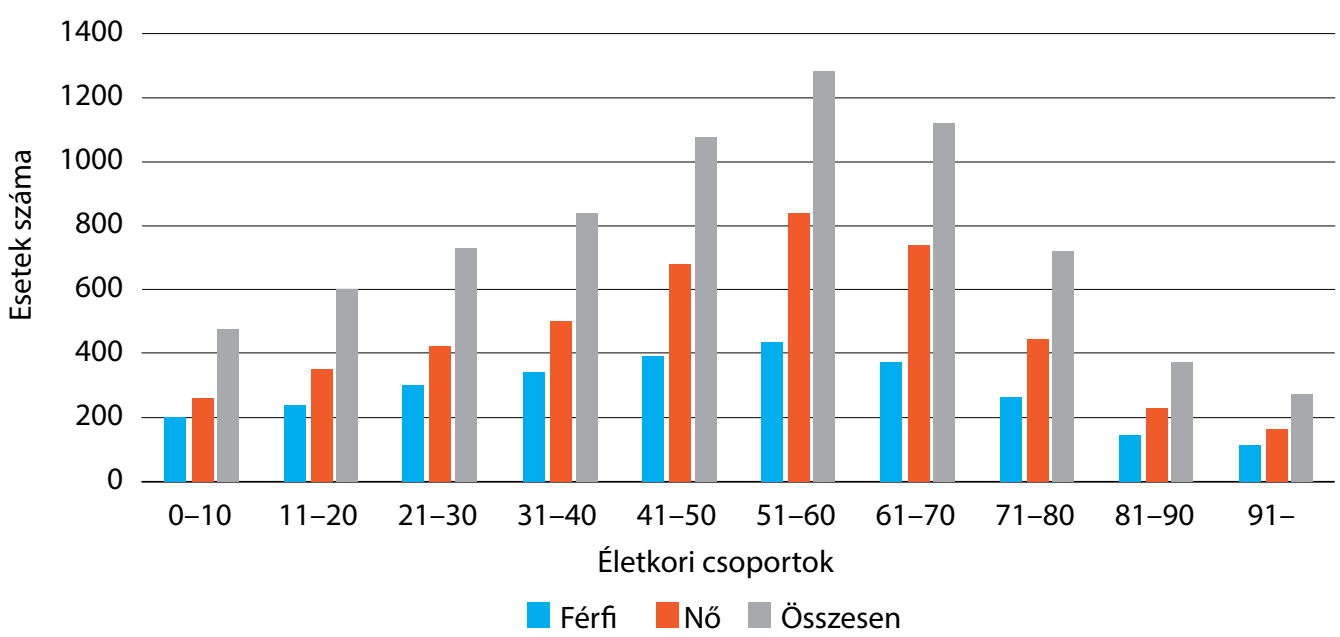

1. ábra

| A jóindulatú daganatok és daganatszerú laesiók megoszlása életkori csoportok és nem szerint 
A daganatok típus szerinti megoszlásában (1. táblázat) gyakoribb volt a nem neoplasticus daganat $(6420$, $85,7 \%)$, mint a neoplasticus daganat (1071, 14,3\%), s csak kevesebb számban fordult elő hámeredetü daganat (982, 13,1\%) a mesenchymalis daganatokhoz (5574, $74,4 \%)$ viszonyítva. A hámeredetû daganatok közül a legtöbb eset papilloma $(423,5,6 \%)$ volt, ezt követte a naevus pigmentosus $(224,3,0 \%)$, a verruca seborrhoica $(212,2,8 \%)$ és a pleomorph adenoma $(60,0,8 \%)$.

A mesenchymalis daganatok közül 3512 (63,0\%) volt traumás és fertőzéses eredetű, amelyek között a leggyakrabban irritációs fibromát (klinikopatológiai diagnózis) (1806, 32,4\%) diagnosztizáltunk, de csökkenő számban előfordult még epulis $(784,14,6 \%)$, fibroepithelialis polyp $(415,7,4 \%)$ és granuloma fissuratum $(370,6,6 \%)$. A gyulladásos/fertőzéses csoportban $(906,16,2 \%)$ a legtöbbször granuloma pyogenicumot $(465,8,3 \%)$ észleltünk, de a granuloma gravidarum $(191,3,4 \%)$ előfordulása is említésre méltó. A fejlődési rendellenességek $(847$, 15,2\%) közül kiemelkedő a haemangioma $(815,14,6 \%)$ incidenciája, és csak kevesebb számban diagnosztizáltunk lymphangiomát $(32,0,6 \%)$. A cysták $(935,12,5 \%)$ gyakorisági sorrendjében a mucokele $(805,10,7 \%)$ után következett a ranula $(69,0,9 \%)$.

Az elváltozások lokalizációját vizsgálva (2. táblázat) a legtöbb esetet, 2081-et $(27,8 \%)$ az ajkon észleltük, ezt követték a gingiván (2024 eset, 27,0\%), a buccán (1069 eset, 14,3\%), a nyelven (981 eset, 13,1\%), az arcbőrön (695 eset, 9,3\%), a szájpadon (481 eset, 6,4\%) és a szájfenéken (160 eset, 2,1\%) regisztrált daganatok. A hámeredetû daganatok tekintetében, mint a papilloma, az előfordulási hely gyakorisági sorrendjében a nyelven 145 $(34,3 \%)$, az alsó ajkon $78(18,4 \%)$, a szájpadon 75 $(17,7 \%)$ és a buccán $39(9,2 \%)$ esetben alakult ki elváltozás. A naevus pigmentosus a legtöbb esetben (178, $79,5 \%)$ a bőrt, míg a pleomorph adenoma $(27,45 \%)$ a kemény szájpadot érintette. A mesenchymalis daganatok közül a fibroma a leggyakrabban a buccán $(642,35,5 \%)$, a nyelven $(321,17,8 \%)$ és az alsó ajkon $(310,17,2 \%)$, míg a granuloma pyogenicum a maxillaris gingiván (138, $29,7 \%)$, a mandibularis gingiván $(98,21,1 \%)$ és a nyelven $(61,13,1 \%)$ fordult elő. A cysták elhelyezkedésében a mucokele a legtöbb esetben az alsó ajkon $(757,94,0 \%)$, a ranula pedig a szájfenéken $(58,84,1 \%)$ alakult ki. Haemangioma a leggyakrabban az alsó ajkon $(349,42,8 \%)$, a nyelven $(149,18,3 \%)$ és a buccán $(117,14,4 \%)$ fejlődött, lymphangioma pedig a nyelven $(14,43,8 \%)$. Az epulis a legtöbb esetben a maxillaris gingiván (488, $62,2 \%)$, majd a mandibularis gingiván $(296,37,8 \%)$, a fibroepithelialis polyp a buccán $(106,25,5 \%)$ és a nyelven $(54,13,0 \%)$, a granuloma fissuratum a mandibularis gingiván $(202,54,6 \%)$, majd a maxillaris gingiván (168, $45,4 \%)$, végül a granuloma gravidarum a maxillaris gingiván $(102,53,4 \%)$ és a mandibularis gingiván (77, $40,3 \%$ ) fordult elő.

Regisztráltunk még egyéb, ritka orofacialis jóindulatú daganatokat: encephalotrigeminalis angiomatosis
(Sturge-Weber-szindróma), 4; Peutz-Jeghers-szindróma, 6; naevus sebaceus, 9; epulis congenitalis, 8; fibromatosis gingivae, 8; neurofibromatosis (morbus Recklinghausen), 9; sclerosis tuberosa (Pringle-Bournevillebetegség), 3; molluscum contagiosum, 9; perifériás odontogen fibroma, 4; hidradenoma (syringoma), 2; adenoma sebaceum, 8; trichoepithelioma, 10; pilomatrixoma, 5; szimmetrikus perifériás fibroma, 10; szimmetrikus benignus lipomatosis, 5; adenoma basocellulare, 2; oncocytoma, 2; canalicularis adenoma, 3; glomustumor (glomangioma), 4; arteriovenosus aneurysma (haemangioma), 3 ; intravascularis haemangioendothelioma (Masson-tumor), 2; cysticus hygroma, 3; neurofibromatosis plexiformis, 1 ; neurofibroma, 5; myxoma, 2; angiokeratoma circumscriptum, 3 ; naevus pigmentosus amelanoticus, 6; naevus coeruleus, 7; naevus verrucosus (Harter naevus), 8; cysta gingivalis neonatalis (Epsteingyöngyök, Bohn-csomók), 8; cysta gingivalis adulta, 3; cysta ductus thyreoglossi, 2; elastosis senilis cysta et comedonica, 9; rhabdomyoma, 1; myofibroma, 2; újszülöttkori melanoticus neuroectodermalis tumor, 1 ; Gardner-szindróma (multiplex fibroma), 2; lingua thyreoidea, 2; angiomyoma, 1 ; chondroma, 1 ; plasmacytoma, 1; angiofibroma, 3; trichilemmoma, 4; angiomyxoma, 1; naevus araneus, 8; xanthoma, 4; condyloma acuminatum, 6 .

\section{Megbeszélés}

A szájüregi jóindulatú lágyrész-daganatokról és daganatszerű elváltozásokról több átfogó tanulmány jelent meg $[1,3,5,6,20,27,32-34,37,40,44-47]$. A vizsgált beteganyag a szegedi Fogászati és Szájsebészeti Klinika Orális Medicina Részlegének jóindulatú, döntően lágyrész-daganatos és daganatszerü elváltozással jelentkező klinikopatológiailag diagnosztizált és számítógép segítségével elemzett eseteit foglalja magában 1960 és 2014 között. Klinikánk 54 éves új járóbeteg-forgalmából 338200 esetre $(2,8 \%)$ derült fény, és a $17454(5,2 \%)$ regisztrált daganatból (jó, prae, rossz) 9482 (54,3\%) volt jóindulatú. A jelen tanulmányba 7491 (42,9\%) beteget vontunk be, ami módszerében közelít a hazai [10] és külföldi vizsgálatokhoz $[1,6]$. A hazai és a külföldi irodalmi közlések összehasonlítása azért nehéz, mert vannak prospektív [12], retrospektív vizsgálatok, különböző korbeli (gyermek [11, 14, 40], felnőtt és gyermek-felnőtt $[1,47])$, időbeli, számbeli, földrajzi, faji eltérések, ezenkívül vannak teljes populációra és populációs mintákra vonatkozó tanulmányok, amelyek eltérően klasszifikált és szelektált diagnosztikus csoportokba tartozó klinikai, szövettani vagy klinikopatológiai adatbázisra épültek $[3,11,24,42]$.

Az életkort tekintve a legtöbb férfi beteg $(443,34,6 \%)$ az 51-60 éves korosztályban volt. A legtöbb megbetegedés a nőknél is ebben a korosztályban fordult elő: 837 eset $(65,4 \%)$. Ez hasonló több szerző eredményéhez [4, 13, 15], de voltak korábbi évtizedeket érintő közlések is. 


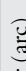

i:

。 畜

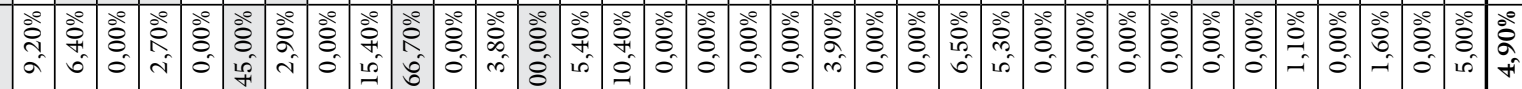

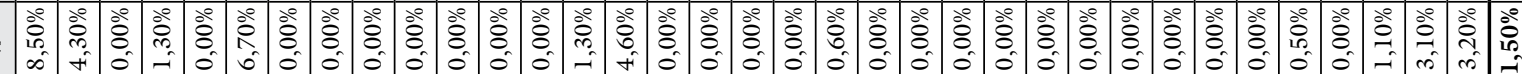

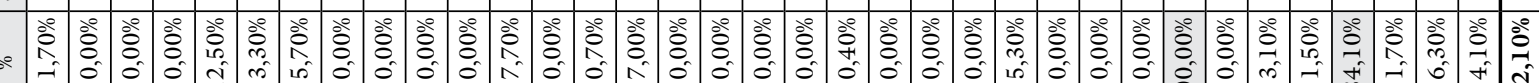

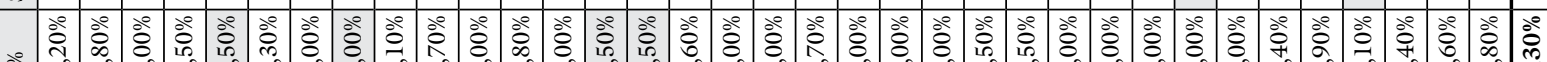

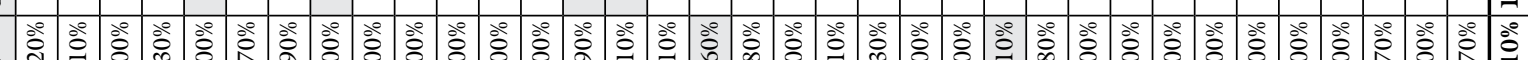

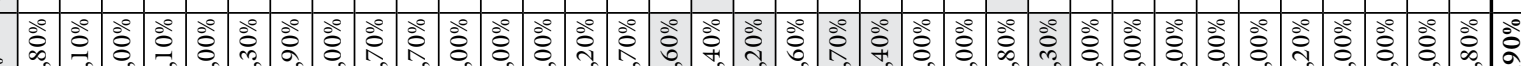

穴

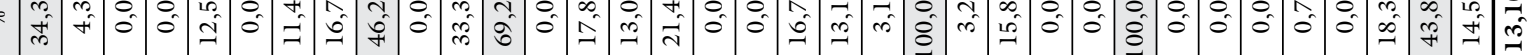

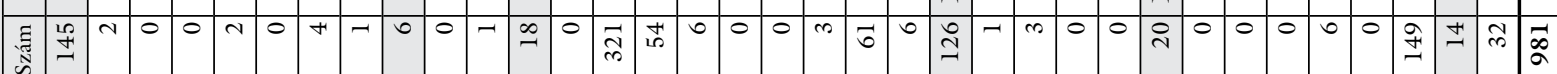

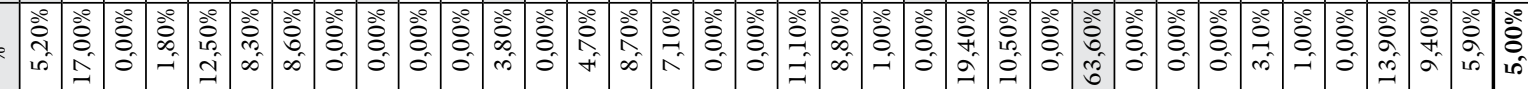

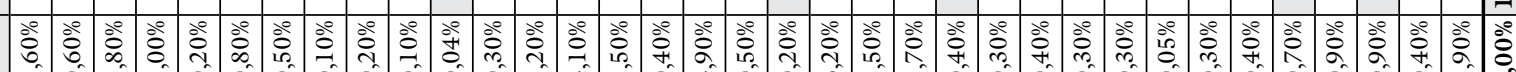

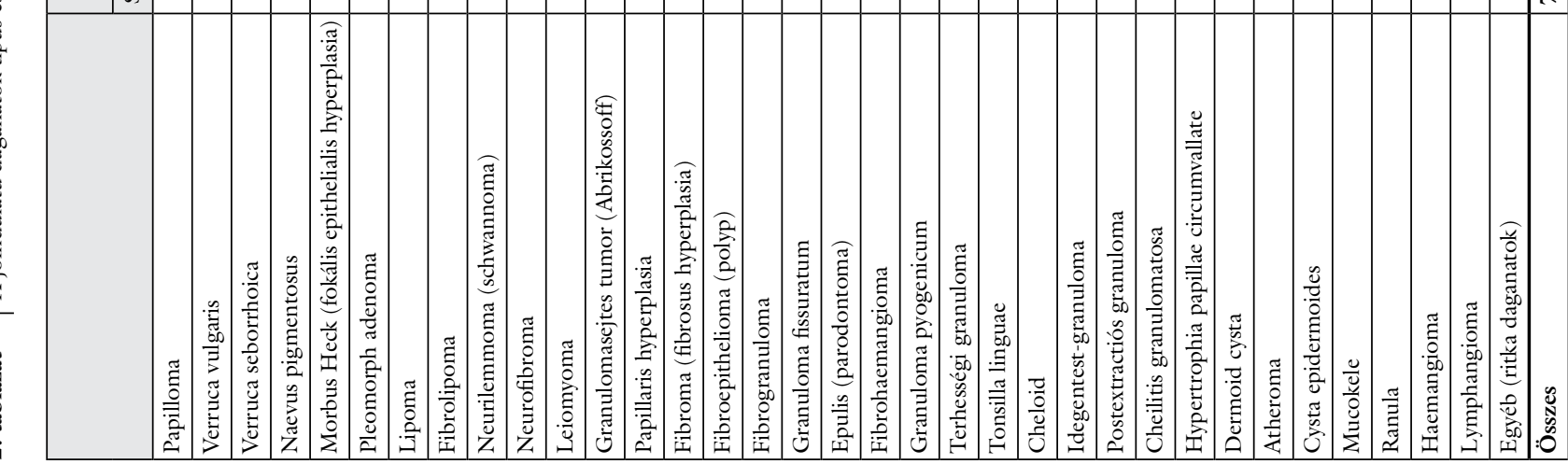


A nemek szerinti megoszlást vizsgálva lényegesen többen vannak a nők $(4668,62,3 \%)$, a férfiak száma kevesebb $(2823,37,7 \%)$. Ez az arány hasonló több külföldi szerző $[4,13,17,24,25,36,40,45,47]$ eredményéhez, de vannak fordított arányú észlelések is [1, 2, 4, 28, 46]. Az utóbbi vizsgálatokban a férfidominanciát az magyarázhatja, hogy az eredmények feldolgozásába a laphámrákot is belevonták. A daganatok szövettani típusára vonatkozóan a szerzők többségéhez hasonlóan [1, 2, 13, $36,40,46]$ a mi elemzésünkben is jóval gyakoribb volt a nem neoplasmák közé sorolt daganatok száma (6420, $85,7 \%)$, mint a neoplasmák előfordulása (1071, 14,3\%). Ezen belül is gyakoribb volt a mesenchymalis daganatok száma $(5574,74,4 \%)$, mint a hámeredetűeké (982, $13,1 \%)$.

Saját vizsgálatunkban a jóindulatú lágyrész-daganatok többsége mesenchymalis és traumás (gyulladásos) eredetü volt $(3512,63,0 \%)$, csökkenő sorrendben a cysták $(935,12,5 \%)$, a gyulladásos fertőzések $(906,16,2 \%)$, a fejlődési rendellenességek $(847,15,2 \%)$ következtek, ami csekély eltéréssel különbözött a külföldi eredményektől $[1,9,13]$. Anyagunkban a cysták felülreprezentáltsága azzal magyarázható, hogy az osztályunkon évtizedek óta alkalmazott termális sebészettel (cryo, lézer) ezek az elváltozások járóbeteg-rendelésen elvégezhetők, elkerülve ezzel a bennfekvéses, esetenként altatásos mütéteket.

Saját vizsgálatunkban a leggyakoribb jóindulatú daganattípus a fibroma $(1806,32,4 \%)$ volt, ami közelít a hazai $[10,11,19,20]$ és külföldi eredményekhez $[2,9,15$, $25,29,36,40,47]$, de voltak olyan közlések, amelyekben a fibroepithelialis polyp [1], a granuloma pyogenicum [13], a papilloma [40], az epulis, lipoma [1, 21], a haemangioma $[1,48]$ és a pleomorph adenoma volt a leggyakoribb.

Hámeredetû papillomát a 11-30 éves korcsoportokban közel azonos nemi eloszlásban észleltünk, fóleg a nyelven (145, 34,3\%), ami megegyezett a korábbi külföldi eredményekkel [1, 20]. Más szerzőktől [40] eltérően csak kevesebb számban $(60,0,9 \%)$ észleltünk pleomorph adenomát, mert osztályunkon döntően csak kisnyálmirigy-adenomát kezeltünk, elsősorban szájpadi elhelyezkedésűeket. A bőrön nagy gyakoriságban regisztráltunk verruca seborrhoicát $(212,3,3 \%)$, amivel a hazai irodalomban nem, a külföldi feldolgozásokban ritkán [40] találkoztunk. Magyarázatul szolgálhat a klinikánkhoz kijelölt három nagy mezőgazdasági megye beteganyaga és az osztályon előnnyel alkalmazható termális sebészeti lehetőség.

A mesenchymalis eredetú irritációs fibroma (1806, $32,4 \%)$ mind a hazai $[10,11,19,20]$, mind a külföldi $[9,15,25,47]$ irodalomban a legmagasabb incidenciát mutatva, a legtöbbször a buccán $[10,11,20]$ alakult ki, döntően fiatal felnőtteken $[10,20,24]$ és nőkön $[1,19$, 20], de férfidominanciát [25] is közöltek. Megállapítható, hogy világszerte a jóindulatú traumás-gyulladásos fibrosus elváltozások a leggyakoribbak $[1,3,6,16,25$, $38,40,46]$.

Nagy számban regisztráltunk epulist $(784,14,6 \%)$, amely a hazai $[10,19,20]$ és a külföldi $[16,29,36]$ eredményekhez hasonlóan többségében a betegek 5170 éves korcsoportjaiban [24], nőknél jelenkezett [10, 19, 36]. Saját anyagunkban maxillaris gingiván fordult elö, de közöltek emelkedett mandibularis [10] érintettséget is, közel azonos gyakoriságban.

Anyagunkban gyakori előfordulást mutatott a pyogen granuloma $(465,8,3 \%)$, amely egyéb vizsgálati eredményekhez hasonlóan a felnőtteknél $[1,13,24]$, dominálóan nőknél [1, 15, 24, 40], és a maxillaris [1] gingiván alakult ki, de volt olyan közlés, amelyben mandibularis lokalizáció vagy közel egyenlő arány volt tapasztalható [24]. A nók érintettségi túlsúlyát az az általános megfigyelés magyarázhatja, hogy a nők gyakrabban járnak fogorvoshoz, mint a férfiak.

Több szerző is megegyezik abban, hogy a reaktív nem neoplasticus elváltozások a leggyakrabban a gingiván alakulnak ki $[1,44]$, igazolva a kiváltó okozat és a lokalizáció közötti olyan összefüggést, miszerint a jól vaszkularizált íny és a gingivalis sulcusban akkumulálódott mikroorganizmusok, a plakk és a fogkő hajlamosító tényezőként szerepelnek [44].

A nem neoplasmás cystás elváltozások közül a mucokele $(805,10,7 \%)$ volt a saját és egyéb feldolgozásban is a leggyakoribb $[1,2,25]$, fooleg az első és a második évtizedben $[1,25]$, elsősorban férfiaknál $[1,25,40]$ és az alsó ajkon-nyelven [1, 25].

Összehasonlítva a vascularis fejlődési anomáliákat, a haemangioma incidenciája kiemelkedik a jelenlegi feldolgozásunkban $(815,14,6 \%)$ a hazai $[10,11,19,20]$ és a külföldi [1, 13, 40, 48] analízisekhez hasonlóan. A fejlődési rendellenességek közé való besorolását az is alátámasztja, hogy már újszülötteknél is észlelhető, és fóleg gyerekeknél és fiatal felnőtteknél [1, 13]; elsősorban az ajkon, a nyelven gyakori, váltakozó női $[10,11,20]$ és férfidominanciában $[13,19,44]$. A haemangioma, de a mucokele vonatkozásában is - egyszerű klinikai diagnosztizálhatóságuk miatt - számos esetben előfordulhat, hogy biopszia nélkül történik a kezelés, így gyakoribb lehet az ilyen elváltozások valós száma.

Az irodalmi közlések [10, 24, 40] alapján a jóindulatú daganatok többségét elsősorban helyi sebészi excízióval kezelték, eltérően a saját klinikai gyakorlatunktól, mert mi döntően biopszia + cyro- vagy lézer- és kombinált (cryo + lézer) kezelést végeztünk.

Nem kétséges, hogy a korai diagnózisnak a praemalignus és a malignus elváltozásoknál van a legnagyobb szerepe, de a jóindulatú daganatok mielőbbi felfedésével, kezelésével további progresszió, szövődmény (fertőzés, funkciózavar, vérzés, malignizáció) kerülhető el.

Több olyan közlemény is megjelent már Magyarországon, amely a tervszerű szájüregi szűrővizsgálatok megvalósításának lehetőségeit [49] és költséghatékonyságát [50] vizsgálja. 
Számítógépes epidemiológiai vizsgálatunk DélkeletMagyarország populációjára irányult, mégis az volt a célunk, hogy olyan adatokat tartalmazzon az egyes jóindulatú orofacialis daganatok és daganatszerú elváltozások multicentrikus eloszlásáról, amelyek az európai és a hazai teljes lakosságra vonatkoztatva is összehasonlítható eredményekkel szolgálja a sztomatoonkológiai epidemiológiát.

Anyagi támogatás: A közlemény megírása, illetve a kapcsolódó kutatómunka anyagi támogatásban nem részesült.

Szerzői munkamegosztás: S. I.: A vizsgálatba bevont betegek felvétele, a biopsziás mintavétel, a kezelés és az utánkövetés végzése. B. K.: A statisztikai analízis elkészítése. D. G.: Az adatok feldolgozásában nyújtott segítség. B. K.: A kézirat szövegének bevitele és szerkesztése. N. K.: A tudományos feldolgozáshoz szükséges intézményi háttér biztosítása. A cikk végleges változatát valamennyi szerző elolvasta és jóváhagyta.

Érdekeltségek: A szerzőknek nincsenek érdekeltségeik.

\section{Köszönetnyilvánítás}

A szerzők köszönetet mondanak Enginé Gyöngyösi Csillának az adatok bevitelében nyújtott segítségéért.

\section{Irodalom}

[1] Al-Khateeb TH. Benign oral masses in a Northern Jordanian population - a retrospective study. Open Dent J. 2009; 3: 147153.

[2] Ali M, Sundaram D. Biopsied oral soft tissue lesions in Kuwait: a six-year retrospective analysis. Med Princ Pract. 2012; 21: 569575 .

[3] Bhaskar SN. Oral pathology in the dental office: survey of 20,575 biopsy specimens. J Am Dent Assoc. 1968; 76: 761-766.

[4] El-Gehani R, Orafi M, Elarbi M, et al. Benign tumours of orofacial region at Benghazi, Libya: a study of 405 cases. J Craniomaxillofac Surg. 2009; 37: 370-375.

[5] Esmeili T, Lozada-Nur F, Epstein J. Common benign oral soft tissue masses. Dent Clin North Am. 2005; 49: 223-240.

[6] Franklin CD, Jones AV. A survey of oral and maxillofacial pathology specimens submitted by general dental practitioners over a 30-year period. Br Dent J. 2006; 200: 447-450.

[7] Happonen RP, Ylipaavalniemi P, Calonius B. A survey of 15,758 oral biopsies in Finland. Proc Finn Dent Soc. 1982; 78: 201206.

[8] Kornbrot A, Tatoian JA Jr. Benign soft tissue tumors of the oral cavity. Int J Dermatol. 1983: 22: 207-214.

[9] Ono Y, Takahashi H, Inagi K, et al. Clinical study of benign lesions in the oral cavity. Acta Oto-laryngol Suppl. 2002; (547): 79-84.

[10] Orosz M, Divinyi T. Incidence of benign soft tissue tumors in the oral cavity, based on the analysis of 306 cases. [Szájüregi jóindulatú lágyrészdaganatok gyakorisága 306 eset elemzése alapján.] Fogorv Szle. 1976; 69: 69-72. [Hungarian]

[11] Orosz M, Vamos I, Gabris K, et al. Childhood tumors in the patient material of 25 years at the Clinic for Oral Surgery and Dentistry. [Gyermekkori tumorok a Szájsebészeti és Fogászati
Klinika 25 éves beteganyagában.] Fogorv Szle. 1978; 71: 193196. [Hungarian]

[12] Parkins GE, Armah GA, Tettey Y. Orofacial tumours and tumour-like lesions in Ghana: a 6-year prospective study. Br J Oral Maxillofac Surg. 2009; 47: 550-554.

[13] Shahsavari F, Khourkiaee S, Moridani S. Epidemiologic study of benign soft tissue tumors of oral cavity in an Iranian population. J Dentomaxillofac Radiol Pathol Surg. 2012; 1: 10-15.

[14] Sklavounou-Andrikopoulou A, Piperi E, Papanikolaou V, et al. Oral soft tissue lesions in Greek children and adolescents: a retrospective analysis over a 32-year period. J Clin Pediatr Dent. 2005; 29 : 175-178.

[15] Torres-Domingo S, Bagan JV, Jimenez Y, et al. Benign tumors of the oral mucosa: a study of 300 patients. Med Oral Patol Oral Cir Bucal 2008; 13: El61-El66.

[16] Weir JC, Davenport WD, Skinner RL. A diagnostic and epidemiologic survey of 15,783 oral lesions. J Am Dent Assoc. 1987; 115: 439-442.

[17] Moshy JR, Sohal KS. The types, incidence and demographic distribution of benign oral and maxillofacial neoplasms among patients attending Muhimbili National Hospital in Tanzania, 2008-2013. Tanzania J Health Res. 2016; 18: 1-5.

[18] Ministry of Health. Methodologic strategy of stomato-oncology. [Egészségügyi Minisztérium. Stomato-onkológiai mószertani levél.] Budapest, 1973. [Hungarian]

[19] Vamos I, Orosz M, Csiba A. Incidence of tumors of the face, jaw and oral cavity. [Arc-állcsonti és szájüregi daganatok gyakorisága.] Fogorv Szle. 1977; 70: 117-123.

[20] Vamos I, Csiba A. Incidence of tumors in the oral cavity. [A szájüregi daganatok gyakorisága.] Fogorv Szle. 1965; 58: 143147. [Hungarian]

[21] Allon I, Kaplan I, Gal G, et al. The clinical characteristics of benign oral mucosal tumors. Med Oral Patol Oral Cir Bucal 2014; 19: e438-e443.

[22] Nascimento GJ, Paraiso DP, Goes PS, et al. Epidemiological study of 2147 cases of oral and maxillofacial lesions. Rev Bras Patol Oral 2005; 4: 82-89.

[23] Bassey GO, Osunde OD, Anyanechi CE. Maxillofacial tumors and tumor-like lesions in a Nigerian teaching hospital: an eleven year retrospective analysis. Afr Health Sci. 2014; 14: 56-63.

[24] Bataineh A, Al-Dwairi ZN. A survey of localized lesions of oral tissues: a clinicopathological study. J Contemp Dent Pract. 2005; 6: 30-39.

[25] Bouquot JE, Gundlach KK. Oral exophytic lesions in 23,616 white Americans over 35 years of age. Oral Surg Oral Med Oral Pathol. 1986; 62: 284-291.

[26] Van der Waal I, Snow GB. Benign tumors and tumorlike lesions of oral cavity and oropharynx. In: Cummings WC. (ed.) Otolaryngology - head and neck surgery. Mosby, St. Louis, MO, 1998.

[27] Gonsalves WC, Chi AC, Neville BW. Common oral lesions: Part II. Masses and neoplasia. Am Fam Phys. 2007; 75: 509-512.

[28] Jahanbani J, Sandvik L, Lyberg T, et al. Evaluation of oral mucosal lesions in 598 referred Iranian patients. Open Dent J. 2009; 3: 42-47.

[29] Simões CA, Lins RC, Henriques AC, et al. Prevalence of diagnostics lesions in maxillofacial region in Oral Pathology Laboratory of Federal University of Pernambuco. Int J Dent. 2007; 6: $35-38$.

[30] Johnson NW. Orofacial neoplasms: global epidemiology, risk factors and recommendations for research. Int Dent J. 1991; 41: $365-375$

[31] Jones AV, Franklin CD. An analysis of oral and maxillofacial pathology found in children over a 30 -year period. Int J Paediatr Dent. 2006; 16: 19-30.

[32] Kovač-Kovačič $M$, Skalerič U. The prevalence of oral mucosal lesions in a population in Ljubljana, Slovenia. J Oral Pathol. 2000; 29: 331-335. 
[33] Lin HC, Corbet EF, Lo EC. Oral mucosal lesions in adult Chinese. J Dent Res. 2001; 80: 1486-1490.

[34] Mathew AL, Pai KM, Sholapurkar AA, et al. The prevalence of oral mucosal lesions in patients visiting a dental school in Southern India. Indian J Dent Res. 2008; 19: 99-103.

[35] Moridani SG, Shaahsavari F, Adeli MB. A 7-year old retrospective study of biopsied oral lesions in 460 Iranian patients. RSBO 2014; 11: 118-124.

[36] Mendez M, Carrard VC, Haas AN, et al. A 10-year study of specimens submitted to oral pathology laboratory analysis: lesion occurrence and demographic features. Braz Oral Res. 2012; 26: 235-241.

[37] Scully C, Porter S. Orofacial disease: update for the dental clinical team: 5. Lumps and swellings. Dental Update 1999; 26: 214-217

[38] Shulman JD, Beach MM, Rivera-Hidalgo F. The prevalence of oral mucosal lesions in U.S. adults: data from the Third National Health and Nutrition Examination Survey, 1988-1994. J Am Dent Assoc. 2004; 135: 1279-1286.

[39] Splieth CH, Sümnig W, Bessel F, et al. Prevalence of oral mucosal lesions in a representative population. Quintessence Int. 2007; 38: 23-29.

[40] Jones AV, Franklin CD. An analysis of oral and maxillofacial pathology found in adults over a 30-year period. J Oral Pathol Med. 2006; 35: 392-401

[41] Avon SL, Klieb HB. Oral soft-tissue biopsy: an overview. J Can Dent Assoc. 2012; 78: c75

[42] Fletcher CD, Unni KK, Mertens F. (eds.) World Health Organization classification of tumours. Pathology and genetics of tumours of soft tissue and bone. IARC Press, Lyon, 2002.

[43] Barnes L, Eveson JW, Reichart P, et al. (eds.) World Health Organization classification of tumours. Pathology and genetics of head and neck tumors. IACR Press, Lyon, 2005.
[44] Neville B, Damn DD, Allen C, et al. Oral and maxillofacial pa thology. 3rd edn. Saunders Elsevier, St. Louis, MO, 2009; pp. 507-552.

[45] Vale EB, Ramos-Perez FM, Rodrigues GL, et al. A review of oral biopsies in children and adolescents: a clinicopathological study of a case series. J Clin Exp Dent. 2013; 5: el44-e149.

[46] Castellanos JL, Díaz-Guzmán L. Lesions of the oral mucosa: an epidemiological study of 23785 Mexican patients. Oral Surg Oral Med Oral Pathol Oral Radiol Endod. 2008; 105: 79-85.

[47] Kelloway E, Ha WN, Dost F, et al. A retrospective analysis of oral and maxillofacial pathology in an Australian adult population. Aust Dent J. 2014; 59: 215-220.

[48] Sato M, Tanaka N, Sato T, et al. Oral and maxillofacial tumours in children: a review. Br J Oral Maxillofac Surg. 1997; 35: 9295.

[49] Döbrőssy L, Bánóczy J, Kovács A, et al. Oral cancer screening: how to develop a country-wide opportunistic system in Hungary. [Szájüregi szűrővizsgálatok: tervek az alkalomszerú szűrés kiterjesztésére Magyarországon.] Orv Hetil. 2007; 148: 12671271. [Hungarian]

[50] Vokó Z, Túri G, Zsólyom A. Cost-effectiveness of oral cancer screening in Hungary. [A szájüregi szűrés költséghatékonysága Magyarországon.] Orv Hetil. 2016; 157: 1161-1170. [Hungarian]

(Buzás Kristóf dr., Szeged, Tisza Lajos krt. 64-66., 6720 e-mail: buzas.kristof@gmail.com)

\section{MEGHÍ Vó}

A Szent Margit Kórház Intézeti Tudományos és Kutatás Etikai Bizottsága tisztelettel meghivja az érdeklődőket a következő tudományos ülésére, amelyet a Nephrologiai Osztály és a Sebészeti Osztály közösen rendez.

Időpont: 2018. szeptember 20. (csütörtök) 14,30 óra

A rendezvény helyszíne: Szent Margit Kórház - Budapest III., Bécsi út 132.

„A" épület, I. emelet, Konferenciaterem

Üléselnök: Dr. Boér Katalin, ITKEB elnökhelyettes

Téma: Vesebeteg-ellátás: az akut beavatkozást igénylő állapotoktól a beteggondozásig

\section{Program:}

Dr. Dolgos Szilveszter: Diagnosztikus kihivások magas anionréssel járó metabolikus acidózisban

Dr. Arányi József: Professzionális életmentő mütét - egy életen át tartó, szinte megoldhatatlan belgyógyászati ellátási probléma

Dr. Haris Ágnes: Az egészségműveltség (health literacy) jelentősége, progressziót befolyásoló szerepe a krónikus (vese)beteg gondozásban

Dr. Somlai Krisztián: Web alapú emlörák adatbázis létrehozása a terhességi és más ritka emlörákos esetekkel kapcsolatos egységes, multicentrikus adatkezelés céljából

Minden érdeklődőt szeretettel várunk. 